\title{
Leontodon saxatilis Lam.: a range-expanding plant or a poorly recognized species in Poland?
}

\author{
Agnieszka Nobis*, Marcin Nobis, Agnieszka Pierścińska \& Anna Trojecka- \\ Brzezińska
}

Department of Plant Taxonomy and Phytogeography, Institute of Botany, Jagiellonian University, Kopernika 27, 31-501 Kraków, Poland, *e-mail: agnieszka.nobis@uj.edu.pl

\begin{abstract}
Until 2001, Leontodon saxatilis was known in Poland almost exclusively from the north-west part. However, numerous localities of the species in southern Poland were reported in recent publications and recorded in our field studies. Data on the distribution and habitat preferences of L. saxatilis at the new localities are presented and its origin in southern Poland is discussed.
\end{abstract}

Key words: Leontodon saxatilis, distribution, range expansion, habitat preferences, Poland

\section{Introduction}

Leontodon saxatilis Lam. has been known for long time, both in Poland (Mirek et al. 2002) and abroad, as Leontodon taraxacoides (Vill.) Mérat. However, according to Bogler (2006), the latter name is a later homonym of Leontodon taraxacoides Hoppe \& Hornschuch. L. saxatilis is native to western Europe

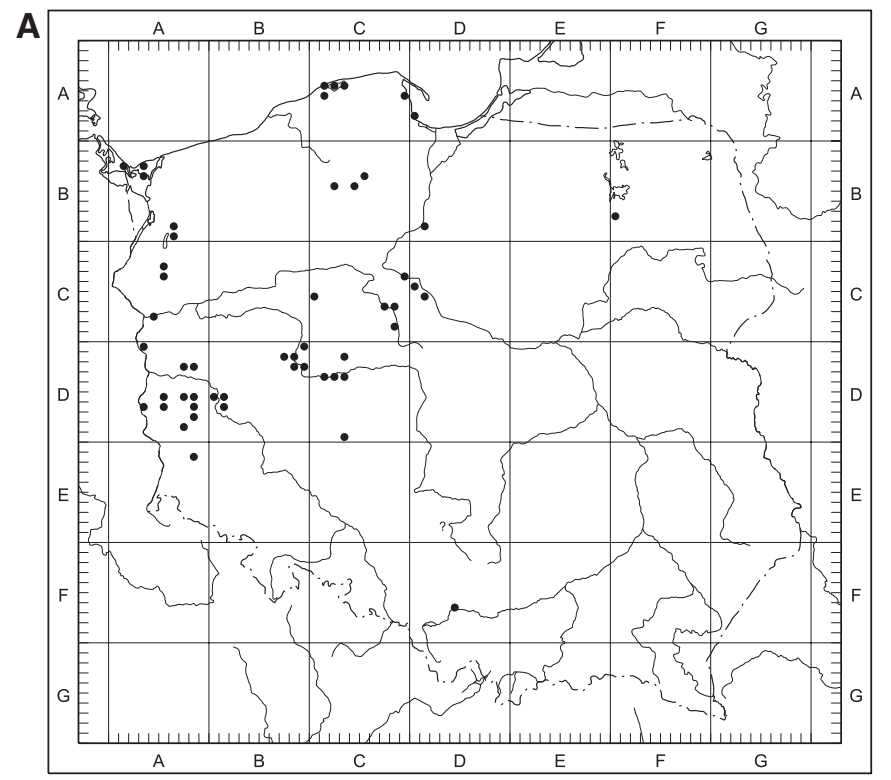

(Hultén \& Fries 1986). It is considered to represent the sub-Atlantic - western Mediterranean distribution type (Zając \& Zając 2009). The species is widely introduced in North America (Bogler 2006) as well as on the southwestern and south-eastern coast of Australia and in Tasmania (Australian Virtual Herbarium 2010).

In Poland, L. saxatilis grows in meadow communities (also on saline substrates) as well as in sandy grasslands,

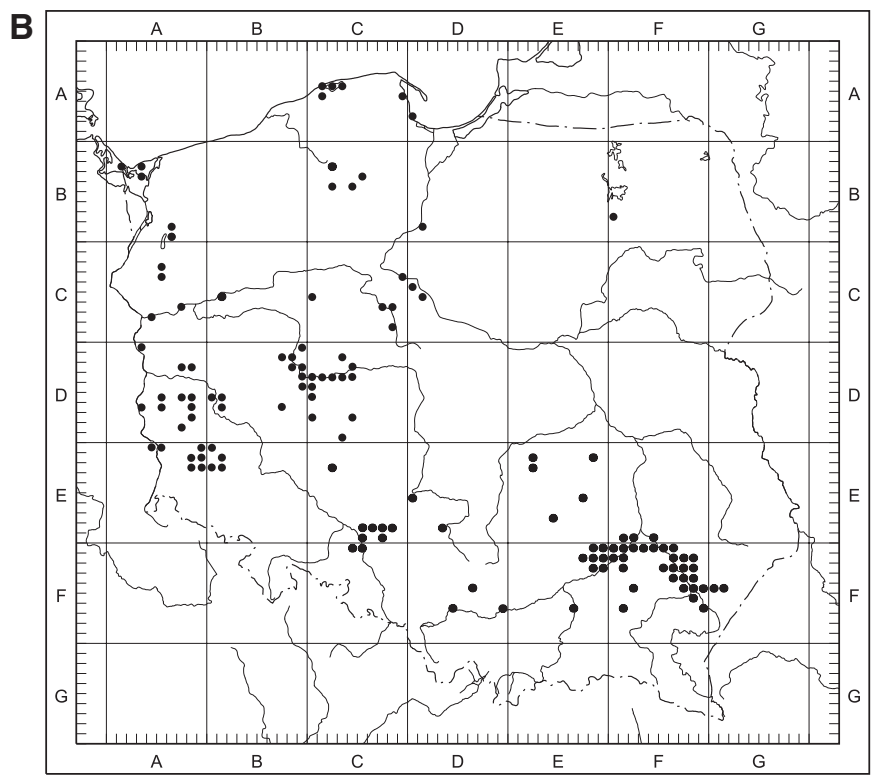

Fig. 1. Distribution of Leontodon saxatilis in Poland

Explanations: A - according to Zając and Zając (2001), B - a map based on the ATPOL database and the data collected after 2001 
on banks of water bodies and in ruderal plant communities (e.g. Pawłowska 1972; Nobis \& Nobis 2008). According to the ATPOL database, it has been reported from ca. 50 localities, mostly in the north-west of Poland (Zając \& Zając 2001) (Fig. 1A). Surprisingly, over 70 new localities of $L$. saxatilis were recorded in southern Poland between 2003 and 2007 (Nobis \& Nobis 2008). Further research conducted by us in southern Poland provided new data on the distribution of the species.

The aim of this paper is to present new information on the occurrence of L. saxatilis in Poland and to discuss the plant's status in the south of the country.

\section{Material and methods}

The present list of localities of L. saxatilis is based on field studies conducted by the authors in 2009-2011, as well as unpublished data collected in 2005 and 2007. The location of localities is based on the ATPOL grid of 10-km squares (Zając 1978).

The distribution of L. saxatilis is mapped using the data provided in the ATPOL database (Zajac \& Zając 2001), studies by Kwiatkowski (2007), Nobis and Nobis (2008), Czarna (2009) and Krawczyk (2010) and the present list of localities (Fig. 1B).

Habitats in which L. saxatilis was recorded were analysed to determine its origin in southern Poland (Fig. 2). The analysis was based on the present data and a study by Nobis and Nobis (2008).

Herbarium specimens of $L$. saxatilis collected by us during field studies are deposited in the Herbarium of the Institute of Botany, Jagiellonian University, Kraków (KRA).

\section{Results and discussion}

In total, 60 new localities of L. saxatilis were recorded (Appendix). The localities listed below are situated in thirty two $10-\mathrm{km}$ cartogram units. They are lo- cated within the Wyżyna Małopolska upland and the Kotlina Sandomierska basin.

L. saxatilis represents quite a broad spectrum of habitat preferences in southern Poland. Data on the occurrence of the species in different habitat types are given in the diagram below (Fig. 2).

L. saxatilis is a component of meadow communities in southern Poland in $41 \%$ of cases reported so far. It was also recorded on roadsides (17\%) and lawns (6\%), mostly along asphalt roads. This indicates that the plant tolerates ground salinity and parching. The contribution of L. saxatilis in habitats such as sandy grasslands, pastures, railway areas, arable fields, fallows or excavations does not exceed $10 \%$ in each. Importantly, the three latter habitats were usually evidently sandy. The species was recorded on a pond weir, pond bank, field baulk or in the cracks in the paving only in single cases. These habitats are classified as 'other' below.

An intentional search for L. saxatilis localities in southern Poland is still indispensable as it will bring important data on the distribution and habitats of the species. However, the distribution map presented here already differs considerably from that published by Zając and Zając (2001) (Fig. 1). It should therefore be asked, whether botanists in southern Poland overlooked the species or whether $L$. saxatilis is spreading.

As an analysis of habitats occupied by L. saxatilis in southern Poland suggests, it seems more likely that the species was poorly recognised in the area. Both a high frequency of records in semi-natural communities (meadows and pastures) and its occurrence in natural communities (sandy grasslands) support this. Localities at which the plant was a component of semi-natural or natural communities constitute over $50 \%$ of all the records examined in the analysis (Fig. 2).

L. saxatilis represents quite a broad spectrum of habitat preferences and it is not chracteristic of any of phytosociological units distinguished in Poland (Matusz-

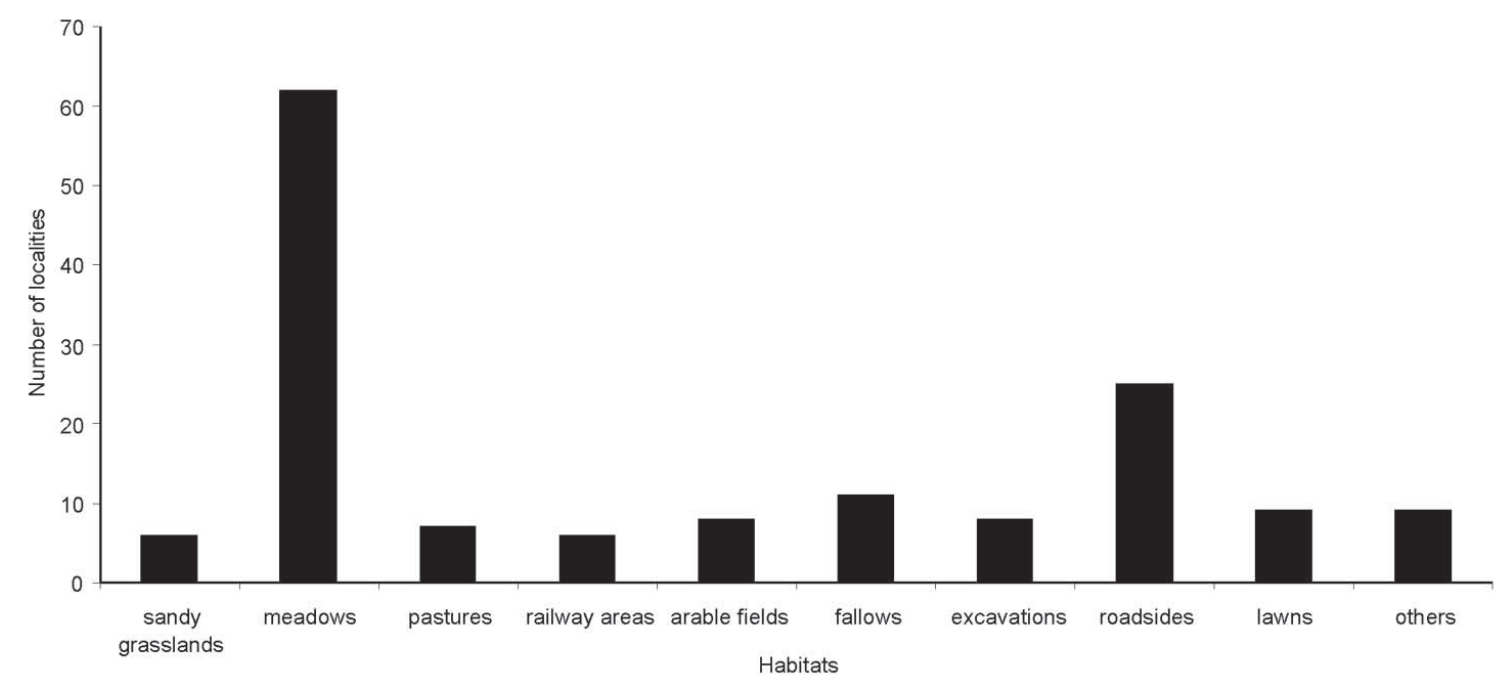

Fig. 2. Occurrence of Leontodon saxatilis in different habitat types in southern Poland 
kiewicz 2001). However, in western Poland it is rather noted as a component of sandy grasslands (cf. Żukowski et al. 1995; Kwiatkowski 2007; Czarna 2009). In Germany, the plant is a component of different types of plant communities, mostly meadows (representing the Molinion alliance or Armerion maritimae alliance), pastures (from the Cynosurion alliance) and flood swards (from the Agropyro-Rumicion alliance) (Rothmaler et al. 2002).

Native character of $L$. saxatilis localities in southern Poland is also confirmed by a considerable concentration of L. saxatilis localities in the eastern part of the Kotlina Sandomierska basin studied in detail by Nobis (2008). The species has not been noted with such a high frequency anywhere else in Poland.

A revision of the herbarium material conducted in two selected Polish herbaria (KRA and KRAM) indicates that some specimens of $L$. saxatilis were incorrectly determined as L. hispidus (Nobis \& Nobis 2008). The fact that some individuals of $L$. saxatilis are coarsely hirsute and easily confused with L. hispidus was discussed in some studies on the genus Leontodon (cf. Bogler 2006).

A relatively low number of localities of $L$. saxatilis in railway areas and along roads does not seem to confirm the hypothesis that the plant spreads linearly from north-western Poland along transport routes. Moreover, as $L$. saxatilis is a threatened species in some lands in Germany (Korneck et al. 1996), belongs to a group of threatened species in Slovakia (EN according to IUCN) (Feráková et al.2001) and represents a group of missing (probably extinct) taxa in the Czech Republic (Holub \& Procházka 2000), it is not very likely that it is an expansive plant in southern Poland.

If the hypothesis that the species was overlooked in southern Poland proves to be correct, the information concerning the occurrence of $L$. saxatilis in this part of the country will be very important for phytogeography as this will shed new light on the course of the taxon's eastern range limit.

\section{References}

Australian Virtual Herbarium 2010. Leontodon saxatilis in Australia (Map displayed on 7. May 2010): http:// www.flora.sa.gov.au/google_maps_avh.html?genus= leontodon\&species=saxatilis\#topmap

Bogler D. J. 2006. Leontodon L. In: M. E. BARKworth, K. M. Capels, S. Long, L. K. Anderton \& M. B. K. Piep (eds.). Flora of North America, 19, pp. 294-296. Oxford University Press, New York-Oxford.

Czarna A. 2009. Rośliny naczyniowe Środkowej Wielkopolski. 184 pp. Wyd. Uniw. Przyrodniczego w Poznaniu, Poznań.

Feráková V., Maglocký Š. \& Marhold K. 2001. Červený zoznam paprad’orastov a semenných rastlín Slovenska (Red list of ferns and flowering plants of Slovakia). Ochr. Prír. 20(Suppl.): 44-77.

Holub J. \& ProcházKa F. 2000. Red List of vascular plants of the Czech Republic - 2000. Preslia 72: 187-230.

Hultén E. \& Fries M. 1986. Atlas of north European Vascular Plants North of the Tropic of Cancer, 2, pp. 943. Koeltz Scientific Books, Königstein.

Korneck D., Schnittler M. \& Vollmer I. 1996. Rote Liste der Fern- und Blütenpflanzen (Pteridophyta et Spermatophyta) Deutschlands. Schr.-R. f. Vegetationskde. 28: 21-187.

KRAWCZYK R. 2010. Notatki florystyczne z północnej części Kotliny Sandomierskiej (SE Polska). Fragm. Flor. Geobot. Polonica 17(1): 9-18.

Kwiatkowski P. 2007. Materiały do flory roślin naczyniowych Borów Dolnośląskich. Annales Silesiae 35: 55-62.

Matuszkiewicz W. 2001. Przewodnik do oznaczania zbiorowisk roślinnych Polski. In: J. B. FALIŃSKI (ed.). Vademecum Geobotanicum, 3, 537 pp. Wyd. Nauk. PWN, Warszawa.
Mirek Z., Piękoś-Mirkowa H., Zając A. \& Zając M. 2002. Flowering plants and pteridophytes of Poland. A checklist. In: Z. MireK (ed.). Biodiversity of Poland, 1, 442 pp. W. Szafer Institute of Botany, Polish Academy of Sciences, Kraków.

Nobis A. 2008. Rośliny naczyniowe wschodniej części Kotliny Sandomierskiej. Prace Bot. 42: 1-341.

Nobis A. \& NoBIs M. 2008. Remarks concerning the distribution of Leontodon taraxacoides (Asteraceae) in Poland. In: P. KoČÁreK, V. PlášeK, K. Malachová \& Š. Cimalová (eds.). Environmental changes and biological assessment. IV. Scripta Facultatis Rerum Naturalium Universitatis Ostraviensis 186: 269-277.

PawŁowska S. 1972. Leontodon L. In: B. PawŁowski \& A. JASIEWICZ (eds.). Flora Polska, 13, pp. 156-170. PWN, Warszawa-Kraków.

Rothmaler W., JÄGer E. J. \& Werner K. 2002. Exkursionsflora von Deutschland. Band 4. Gefäßpflanzen: Kritischer Band. 948 pp. Spektrum Akademischer Verlag Heidelberg-Berlin.

ZAJAc A. 1978. Atlas of distribution of vascular plants in Poland (ATPOL). Taxon 27(5-6): 481-484.

Zając A. \& Zając M. (eds.). 2001. Distribution Atlas of Vascular Plants in Poland. xii+714 pp. Edited by Laboratory of Computer Chorology, Institute of Botany, Jagiellonian University, Cracow.

ZajĄC M. \& ZajĄC A. 2009. The geographical elements of native flora of Poland. 94 pp. Edited by Laboratory of Computer Chorology, Institute of Botany, Jagiellonian University, Kraków.

Żukowski W., Latowski K., JaCkowiak B. \& Chmiel J. 1995. Rośliny naczyniowe Wielkopolskiego Parku Narodowego. Prace Zakładu Taksonomii Roślin UAM w Poznaniu 4: 1-229. Bogucki Wyd. Nauk. Poznań. 


\section{Appendix. List of new localities of Leontodon saxatilis in Poland}

Lódzkie voivodeship: EE12: Bielowice (ca. $6 \mathrm{~km}$ NEE of Opoczno), mesic meadow, observed by A. Trojecka-Brzezińska, 2009; Opoczno (E part of the town), meadow (by a river), leg. A. Trojecka-Brzezińska, 31.08.2009; EE22: Skronina (ca. 12 km SE of Opoczno), mesic meadow, leg. A. Trojecka-Brzezińska, 28.07.2007.

Świętokrzyskie voivodeship: EE32: Sierosławice, mesic meadow, observed by A. Trojecka-Brzezińska, 2010; EE42: Kazanów (along the road towards Modliszewice), roadside, observed by A. Trojecka-Brzezińska, 2010; EE74: Kielce (Niewachlów II district) (near the ring road junction and Łódzka St.), lawn, observed by A. \& M. Nobis, 08.2009; EF08: Oględów (ca. 2 km W of Staszów), pasture, leg. A. Pierścińska, 30.06.2005; EF09: Granicznik (ca. 5 km NW of Osiek), mesic meadow, observed by A. Pierścińska, 08.2009; EF17: Strzelce (ca. 2.5 km NW of Oleśnica), mesic meadow, observed by A. Pierścińska, 09.2009; Budy (ca. 1 km N of Oleśnica), mesic meadow, leg. A. Pierścińska, 10.09.2009; EF18: Wilkowa (ca. 7 km NWW of Połaniec), mesic meadow, leg. A. Pierścińska, 7.09.2009; Ruda (ca. 4 km NNW of Połaniec), a pond weir, leg. A. Pierścińska, 14.07.2009; EF19: N of Mucharzów (ca. 6 km W of Osiek), fallow, leg. A. Pierścińska, 6.07.2009; Podlasie (ca. 4 km W of Osiek), mesic meadow, observed by A. Pierścińska, 08.2009; Ossala (ca. 8 km NE of Połaniec), fallow, leg. A. Pierścińska, 30.06.2009; Okrągła (ca. 3 km NNE of Połaniec), mesic meadow, leg. A. Pierścińska, 2.07.2007; EF28: Borzymów (ca. 3 km SE of Oleśnica), fallow, leg. A. Pierścińska, 1.07.2009; Orzelec Mały (ca. 6 km NE of Pacanów), pasture, leg. A. Pierścińska, 7.08.2009; Łubnice, arable field, leg. A. Pierścińska, 26.08.2009; EF29: Połaniec-Zawada (by a power plant), lawn, leg. A. Pierścińska, 24.08.2009; Kolonia Tursko Małe (ca. 6 km NEE of Połaniec), mesic meadow, observed by A. Pierścińska, 08.2009; FE92: Sandomierz (Żwirki i Wigury St.), lawn, observed by M. Nobis, 07.2009; FF00: Jeziory (ca. 5 km NW of Łoniów), pasture, 22.09.2009, leg. A. Pierścińska; Suliszów (ca. 3 km NW of Łoniów), mesic meadow, observed by A. Pierścińska, 09.2009; N of Suchowola near Osiek, mesic meadow, leg. A. Pierścińska, 21.07.2009; Grabowiec (ca. 2 km N of Osiek), fallow, leg. A. Pierścińska, 20.07.2009; FF10: Suchowola (ca. 2 km NW of Osiek), mesic meadow, leg. A. Pierścińska, 21.07.2009; Osiek, roadside, leg. A. Pierścińska, 28.09.2009; FF11: Łążek (ca. 7 km SW of Tarnobrzeg), mesic meadow, 29.07.2009, leg. A. Pierścińska.

Małopolskie voivodeship: EF66: near the water treatment plant in Wierzchosławice (ca. 2 km E of Tarnów), roadside, leg. M. Nobis, 15.07.2009.

Podkarpackie voivodeship: FF01: Przewłoka (ca. $3 \mathrm{~km} \mathrm{SW}$ of Tarnobrzeg), on wet sand in the Machów mine, observed by A. \& M. Nobis, 2005; FF03: Grębów near Stalowa Wola, mesic meadow (in the vicinity of ponds), observed by A. \& M. Nobis, 2005; FF25: ca. 5 km S of Rudnik, mesic meadow and sandy edge of a pond, leg. A. \& M. Nobis, 15.07.2011; FF26: ca. $5 \mathrm{~km}$ SSW of Rudnik, sandy roadside in a pine forest, leg. A. \& M. Nobis, 15.07.2011; FF36: SW of buildings on the W border of Łukowa near Ruda Łańcucka, mesic meadow, leg. A. Nobis, 19.06.2009; Nowa Sarzyna - SE part of the town (Janda estate), lawn, leg. A. Nobis, 23.06.2009; FF37: ca. $1.5 \mathrm{~km}$ E of the S border of Kulno near Leżajsk, wet sandy roadside by a forest nursery, leg. A. Nobis, 11.07.2009; ca. $1.5 \mathrm{~km} \mathrm{SE}$ of the S border of Kulno near Leżajsk, mesic meadow, leg. A. Nobis, 11.07.2009; ca. $1.5 \mathrm{~km} \mathrm{~N}$ of the $\mathrm{N}$ border of Przychojec near Leżajsk (by the SW end of the fencing at a production plant), mesic meadow, leg. A. Nobis, 18.06.2009; E of the S border of the Niemcy estate near Łukowa, mesic meadow, leg. A. Nobis, 19.06.2009; FF38: ca. $1.5 \mathrm{~km}$ NE of the cemetery in Piskorowice near Leżajsk, mesic meadow, leg. A. Nobis 1.07.2009; ca. $1 \mathrm{~km}$ NE of the welfare centre in Mołynie (NE of Piskorowice), sandy roadside in a pine forest, leg. A. Nobis, 30.06.2009; ca. $100 \mathrm{~m} \mathrm{~W}$ of former state-owned Cieplice buildings (by an asphalt road), fallow, leg. A. Nobis, 29.06.2009; FF42: Kolbuszowa (in the vicinity of a church), lawn, leg. A. \& M. Nobis, 5.08.2009; FF47: ca. 1.5 km NNE of Grodzisko Górne entrance from Giedlarowa, mesic meadow by the forest, leg. A. Nobis, 24.06.2009; ca. $2.5 \mathrm{~km} \mathrm{NE}$ of Grodzisko Górne entrance from Giedlarowa, mesic meadow by the forest, leg. A. Nobis, 25.06.2009; ca. $500 \mathrm{~m}$ N of the junction in Grodzisko Górne (by the village entrance from Giedlarowa), lawn, A. Nobis, 24.06.2009; ca. $1 \mathrm{~km} \mathrm{SW}$ of the level crossing between Dębno and Wierzawice (near Leżajsk), mesic meadow, 27.06.2009, leg. A. Nobis; FF48: E of a shrine near Leżachów entrance from Sieniawa, wet sandy fallow, leg. A. Nobis, 13.07.2009; ca. $500 \mathrm{~m}$ E of the NE border of Leżachów (along a field road towards the asphalt road), in ditches, leg. A. Nobis, 13.07.2009; FF49: ca. $500 \mathrm{~m} \mathrm{~S}$ of the eastern border of Dybków near Sieniawa, fallow, leg. A. \& M. Nobis, 15.07.2009; section 251, ca. $5 \mathrm{~km}$ NEE of Czerce (near Sieniawa), sandy forest roadside, leg. A. \& M. Nobis, 21.08.2009; ca. $1 \mathrm{~km} \mathrm{~S}$ of Dobcza (ca. $5 \mathrm{~km}$ SE of Adamówka), a sand excavation by the forest, leg. A. \& M. Nobis, 22.08.2009; by a church in Dobra (ca. $7 \mathrm{~km} \mathrm{~S}$ of Adamówka), in the cracks in the paving, leg. A. \& M. Nobis, 20.08.2009; NE of a church in Dobra (ca. $6 \mathrm{~km} \mathrm{~S}$ of Adamówka), mesic meadow, leg. A. \& M. Nobis, 9.08.2009; FF58: ca. $250 \mathrm{~m} \mathrm{NE}$ of the Za Łączką settlement (near Leżachów), mesic meadow, leg. A. \& M. Nobis, 15.07.2009; E part of Gniewczyna Tryniecka, lawn, leg. A. \& M. Nobis, 22.07.2009; FF69: NW of Jarosław (near buildings in the Kurhel Pełkiński estate), mesic meadow, leg. A. \& M. Nobis, 23.07.2009; GF40: ca. 2.5 km SSW of Dzików Stary (ca. $25 \mathrm{~km}$ NEE of Sieniawa), wet sandy arable field, leg. A. \& M. Nobis, 12.07.2011; GF41: ca. 2.5 km S of Dzików Stary ca. 25 km NEE of Sieniawa), mesic meadow, observed by A. \& M. Nobis, 13.07.2011. 